\title{
WATER FROM THE COASTAL
}

PLAIN AQUIFERS IN THE

\section{WASHINGTON, D.C.,}

\section{METROPOLITAN AREA}

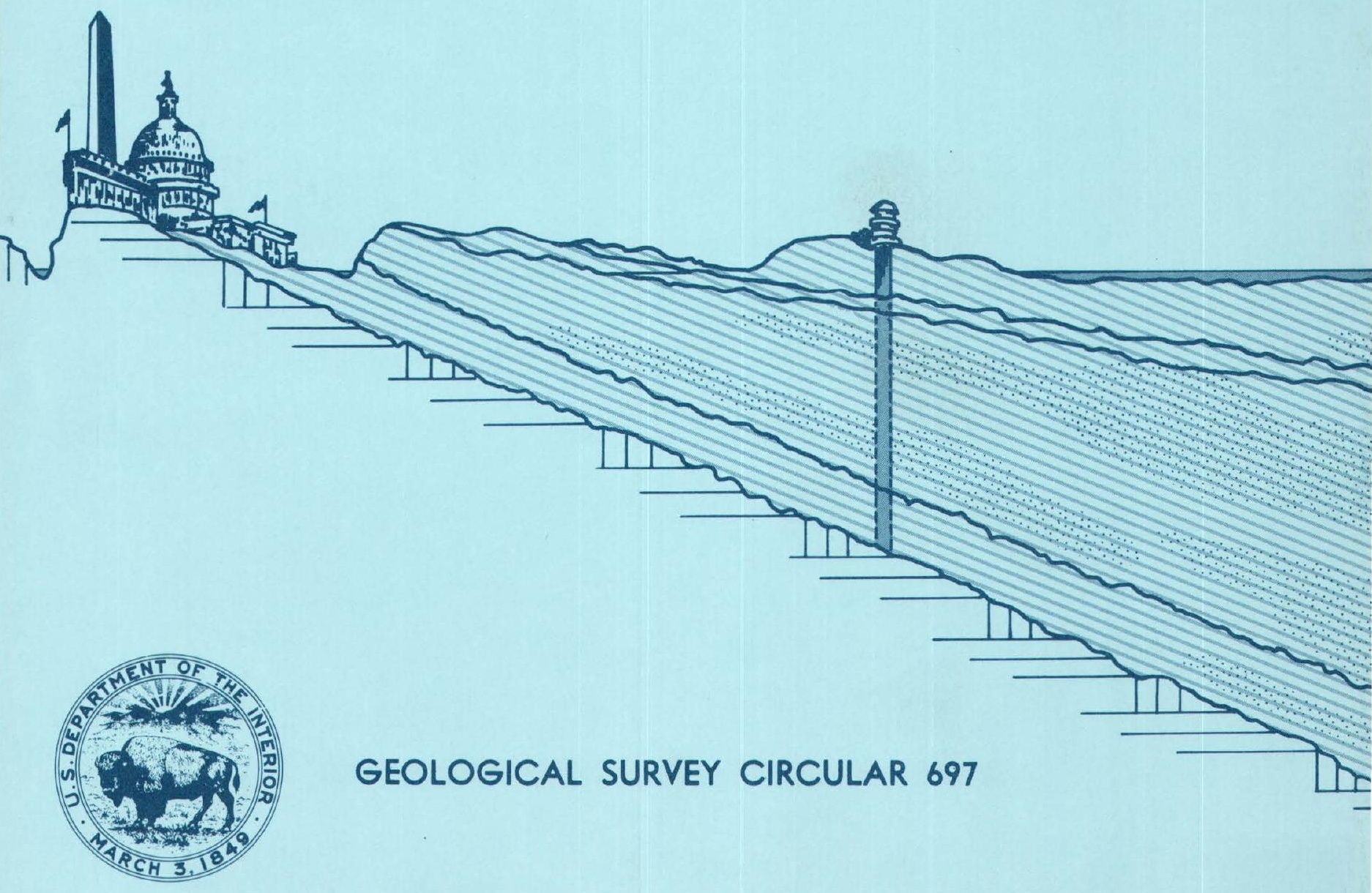



Water From the Coastal

Plain Aquifiers in the

Washington, D.C.,

Metropolitan Area

By S. S. Papadopulos, R. R. Bennett, F. K. Mack, and P. C. Trescott

GEOLOGICAL SURVEY CIRCULAR 697 
United States Department of the Interior

ROGERS C. B. MORTON, Secretary

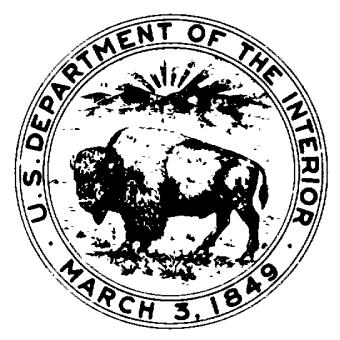

Geological Survey

V. E. McKelvey, Director 


\section{CONTENTS}

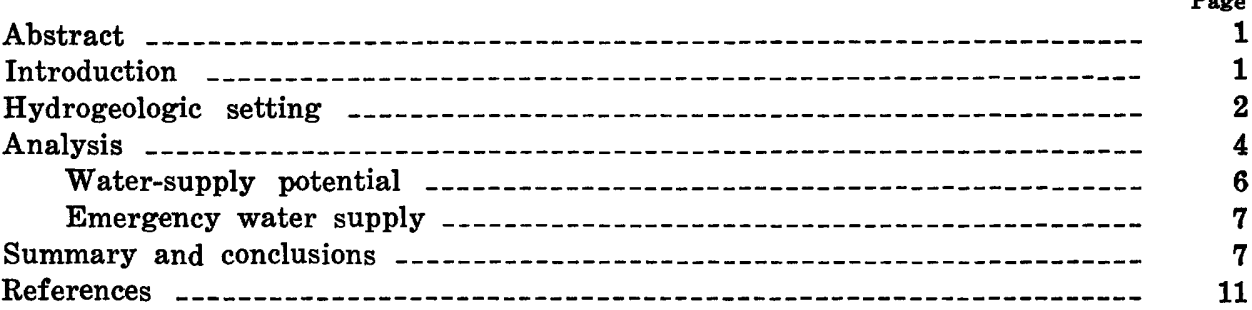

Abstract -

Introduction

Hydrogeologic setting _._.

Analysis

Water-supply potential

Emergency water supply

References

\section{ILLUSTRATIONS}

Figures 1-6. Map showing-

Page

1. Location of the study area

\section{2}

2. Transmissivity of the Magothy aquifer

3. Transmissivity of the Patapsco aquifer

4. Transmissivity of the Patuxent aquifer

$\bar{d}$

5. Model area and locations of boundaries and of hypothetical well field

6. Drawdown at the end of the third 100-day pumping cycle

7. Plan and section of idealized well configuration at a test site -- 



\title{
Water from the Coastal Plain Aquifers in the Washington, D.C., Metropolitan Area
}

\author{
By S. S. Papadopulos, R. R. Bennett, F. K. Mack, and P. C. Trescott
}

ABSTRACT

A brief study of the Atlantic Coastal Plain aquifers in the vicinity of the Washington, D.C., metropolitan area was made, using available data, to estimate the water-supply potential of these aquifers and to determine the possibility of developing an emergency water supply during droughts. Assuming that the data available are representative, the study indicates that the water-supply potential of these aquifers, within an assumed 30-mile radius of Washington, D.C., is about 170 million gallons per day. That is, these aquifers, which are now furnishing an estimated 60 million gallons per day, could be developed to supply an additional 110 million gallons per day on a continuous basis. This quantity might be even larger if a significant amount of water is derived from leakage through finer grained confining beds, but further studies would be necessary to determine the amount of leakage and the long-term effects of large-scale continuous use. Furthermore, under intermittent pumping conditions, an assumed emergency supply of 100 million gallons per day could probably be developed from well fields within a 30-mile radius of Washington. An exploration and testing program would be necessary to assess the reliability of these preliminary estimates.

\section{INTRODUCTION}

On September 20, 1972, at the request of the Washington Area Interstate Water Resources Program Task Force, a meeting was held between representatives of the Task Force, the U.S. Geological Survey, the Virginia State Water Control Board, Division of Water Resources, and the Maryland Water Resources Administration. At this meeting, the Task Force requested information on the following:

1. Development possibilities of ground water in and around the Washington metropolitan area, within the Potomac and Patuxent River basins;

2. Possibilities and problems of artificially re- charging the aquifers to increase yields; and

3. Possibilities for the use of aquifers as reservoirs to augment streamflow during lowflow periods.

To investigate these possibilities, a work force was formed consisting of J. T. Callahan (chairman), R. R. Bennett, F. K. Mack, S. S. Papadopulos, P. C. Trescott and R. L. Wait, all of the U.S. Geological Survey, E. W. Ramsey of the Virginia State Water Control Board, Division of Water Resources, and Arnold Schiffman of the Maryland Water Resources Administration.

As members of this work force, the authors made a quick reconnaissance analysis by digital simulation of the Coastal Plain aquifers, on the basis of available geologic and hydrologic data. The study was confined to the first item of the Task Force request. Specifically, the objectives of the analysis were:

1. To estimate the water-supply potential of these aquifers in the Washington metropolitan area; and

2. To determine the possibility of developing an assumed emergency water supply of $100 \mathrm{mgd}$ (million gallons per day) during droughts.

The results of the study were included in an administrative letter submitted to the Washington Area Interstate Water Resources Program Task Force on November 9, 1972, with appropriate references to the preliminary nature of the results due to the potential inaccuracies in such an analysis.

The Task Force later requested the U.S. Geological Survey, by letter of April 9, 1973, to formulate a testing program that would be needed to assess the reliability of the digital 
simulation results, and this program was formulated and submitted to the Task Force by letter of June 4, 1973.

The purpose of this circular is to present the data used and the assumptions made in the simulation of the aquifers and the results of the analysis and to describe a drilling and testing program that could be implemented to assess the reliability of these preliminary results.

The Task Force was charged with the objective of preparing an implementable action program to (1) alleviate immediate or short-term problems of providing sufficient water supply of good quality to meet demands and to (2) provide for the reduction of pollutants entering the Potomac River to reduce its polluted condition. To the extent that the U.S. Geological
Survey is requested to assess the water-resources aspects of other alternatives, the basic data and their evaluation will be published in subsequent circulars.

\section{HYDROGEOLOGIC SETTING}

The middle Atlantic Coastal Plain is the region that lies southeast of a line extending from Richmond, Va., northeast through the Washington metropolitan area and Baltimore, Md. (See fig. 1.) The hydrogeology of various parts of the Coastal Plain in the vicinity of the Washington metropolitan area has been discussed in many reports (Brookhart and Bennion, 1949; Bennett and Meyer, 1952; Meyer, 1952; Otton, 1955; Johnston and others, 1962; Mack, 1962, 1966, 1974; Johnston, 1964; Otton

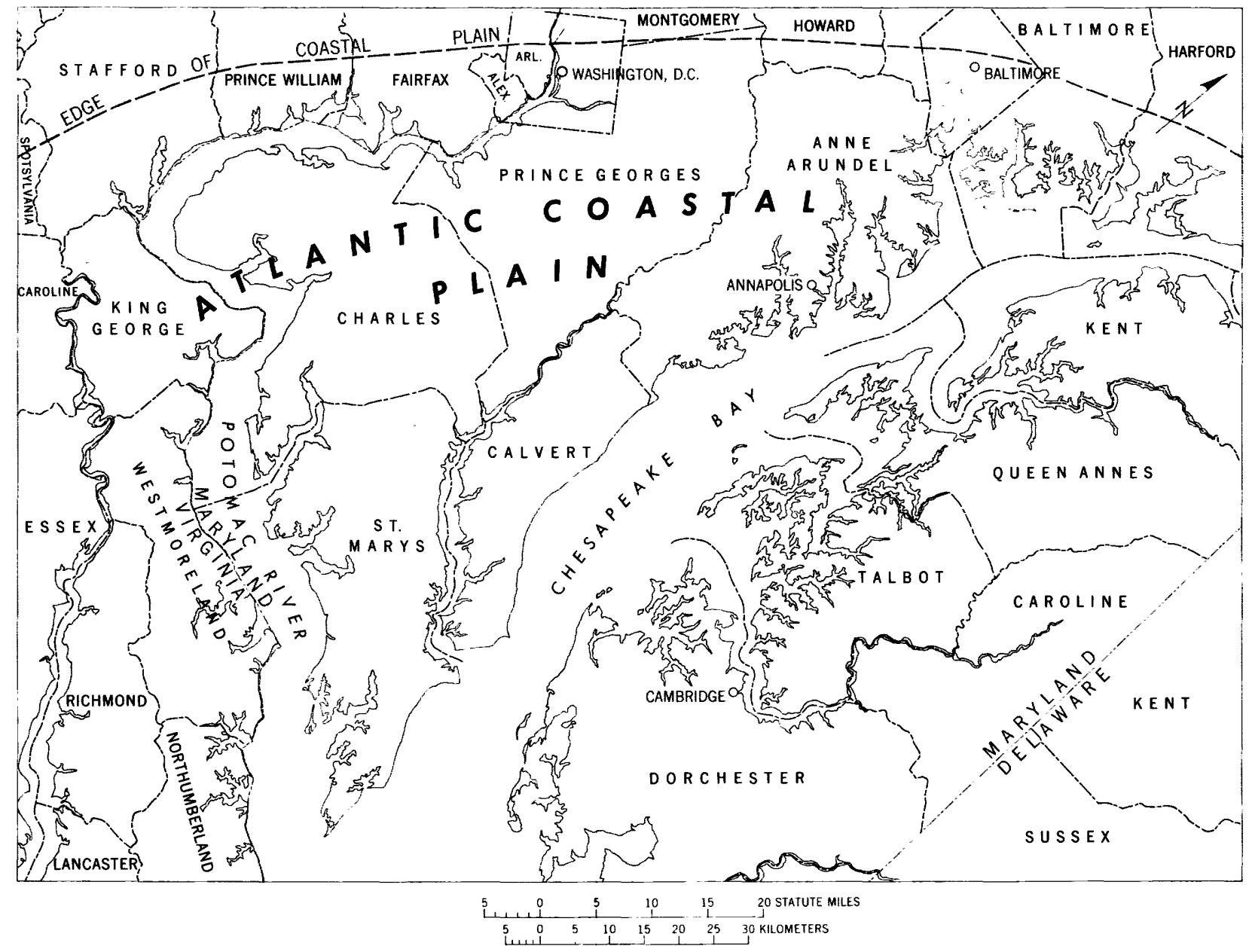

Figure 1.-Location of study area. 
and others, 1964; Back, 1966; Crooks and others, 1967; Slaughter and Otton, 1968; Weigle and others, 1970; Cederstrom and others, 1971; Hansen, 1972; Brown and others, 1972; Cushing and others, 1973).

In brief, the Coastal Plain is underlain by a wedge-shaped mass of sediments ranging in thickness from near zero at the inland edge of the Coastal Plain to more than 2,000 feet about 30 miles southeast of Washington. Extensive layers of sand and gravelly sand within this wedge-shaped mass, which is composed largely of silt and clay, form the primary Coastal Plain aquifers-known as the Magothy, the Patapsco, and the Patuxent, in order of increasing depth of occurrence below land surface. These aquifers crop out in ill-defined bands several miles wide parallel to the edge of the Coastal Plain and dip to the southeast toward the coast beneath younger sediments. With the exception of these outcrop areas, water in the aquifers occurs under confined (artesian) conditions. The aquifers receive recharge from precipitation at places within the outcrop areas and probably from leakage through the confining beds in some areas.

Transmissivity ${ }^{1}$ maps for the Magothy, Patapsco, and Patuxent aquifers, prepared on the basis of available aquifer test data (Bennett and Meyer, 1952; Otton, 1955; Mack, 1962, 1966, 1974; Otton and others, 1964; Slaughter and Otton, 1968), are shown in figures 2-4. The combined transmissivity of the aquifers

1 Transmissivity is the rate at which water is transmitted through a unit width of the aquifer under a unit hydraulic gradient.

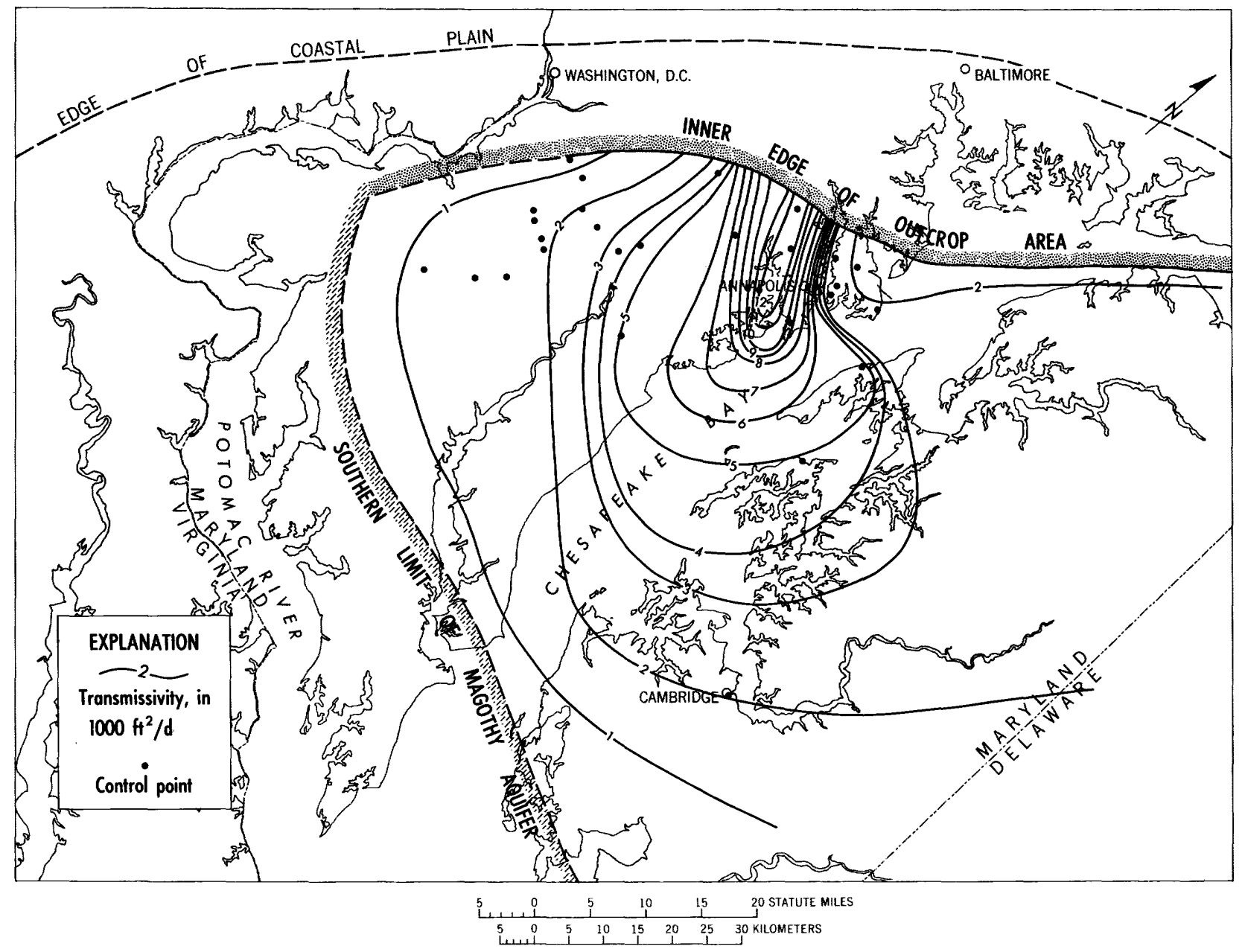

FIGURE 2.-Transmissivity of the Magothy aquifer. 


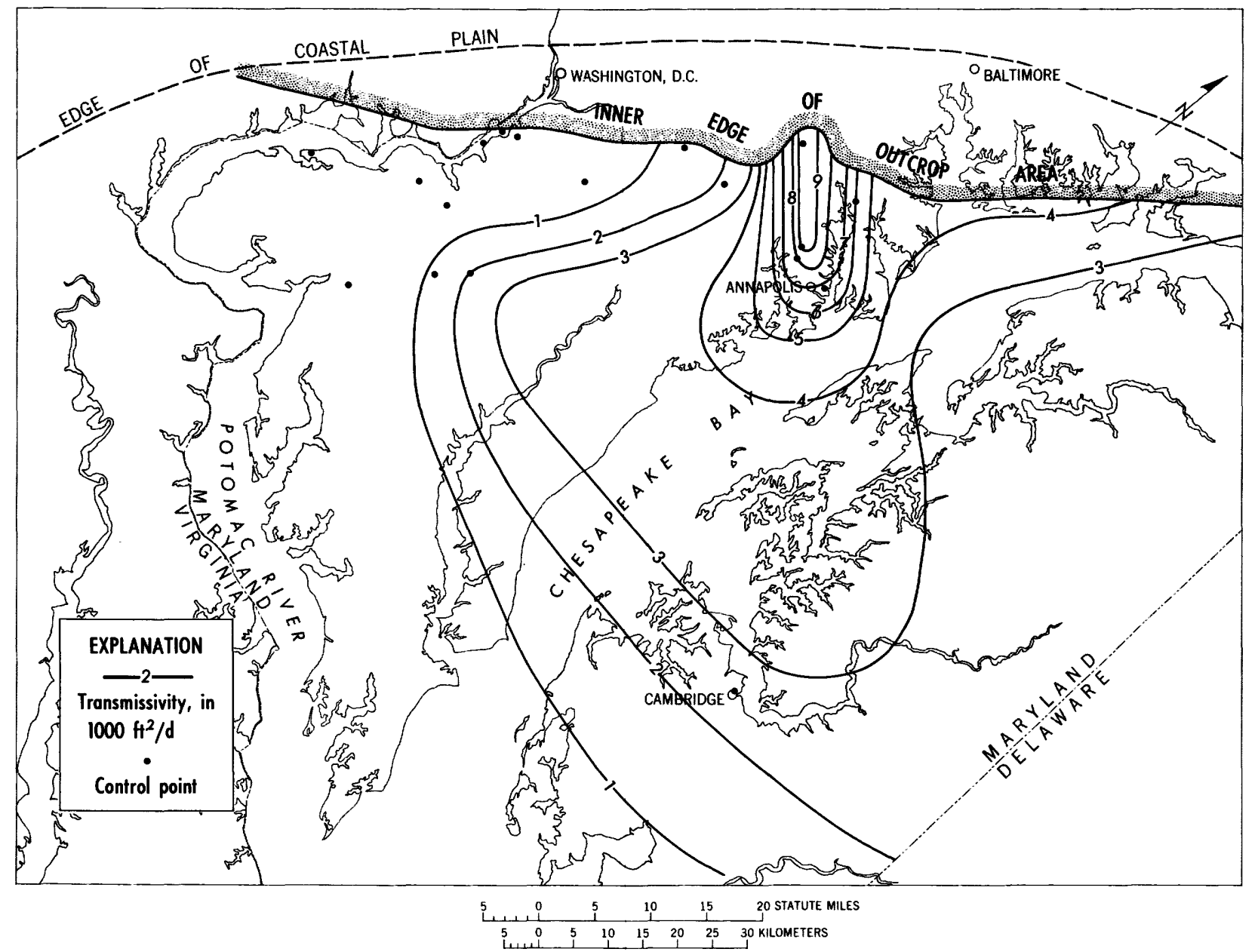

FIGURE 3.-Transmissivity of the Patapsco aquifer.

ranges from $1,000 \mathrm{ft}^{2} / \mathrm{d}$ (feet squared per day) in the south to $25,000 \mathrm{ft}^{2} / \mathrm{d}$ northeast of Washington, where the aquifers are thicker and more permeable.

Present pumpage from these aquifers in the vicinity of the Washington metropolitan area is estimated to be $30 \mathrm{mgd}$ for public, industrial, and institutional water supplies in Charles, Prince Georges, and Anne Arundel Counties in Maryland. In addition, many small domestic systems use ground water. On the basis of estimates of population not served by public water supplies, pumpage by domestic systems may be as much as $\mathbf{3 0} \mathrm{mgd}$, bringing the total estimate of pumpage to $60 \mathrm{mgd}$. About $34 \mathrm{mgd}$ of this estimated total is pumped in Anne Arundel County, mainly in an area of high transmissivity north of Annapolis.
The chemical quality of water from the Coastal Plain aquifers, in various locations near the Washington metropolitan area, has been discussed by Otton (1955), Mack (1962, 1966, 1974), and Slaughter and Otton (1968). In general, the quality differs from place to place and from aquifer to aquifer at the same site. Although untreated ground water in some areas is satisfactory for use in public watersupply systems, water in other areas may require conventional treatment to correct for acidity, high iron content, or excessive hardness.

\section{ANALYSIS}

The customary technique used to analyze the water-supply potential of an aquifer system in a way that permits study of the reaction of the 


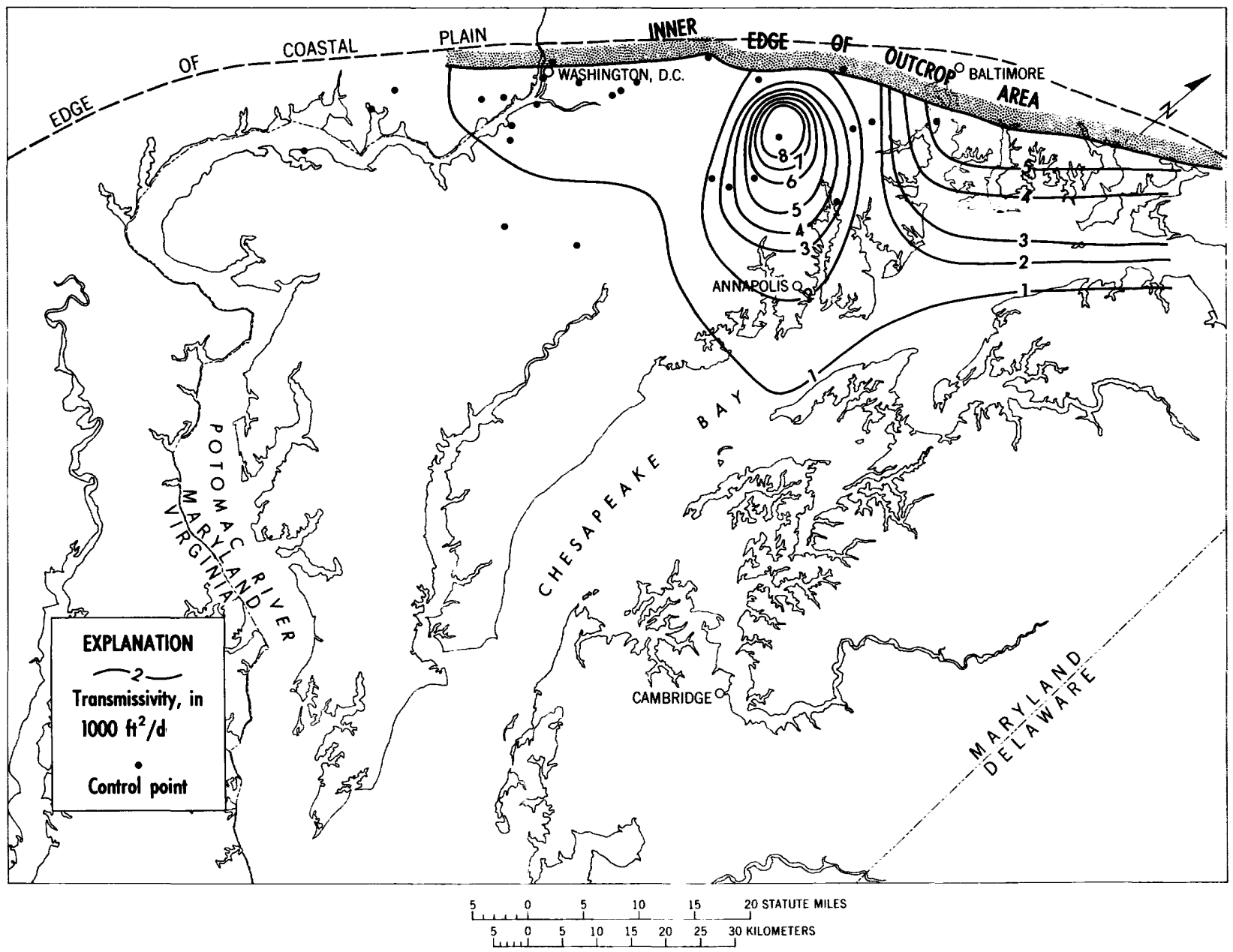

FigURe 4.-Transmissivity of the Patuxent aquifer.

system to various assumed conditions of development is to create a digital computer model of the system. Such a model incorporates all that is known about the geologic setting, the physical boundaries, and the hydrologic characteristics of the aquifer or aquifers. When a model is completed, the conditions under which the aquifer system will be operated must be defined or assumed in order to use the model to predict how water levels or the water yield will be affected under these assumed conditions.

To attain the objectives of this study, the Coastal Plain aquifers were simulated by a mathematical digital computer model that was first developed and later revised by U.S. Geological Survey scientists (Pinder, 1970; Trescott, 1973). To estimate the effects of largescale ground-water development, an area much larger than the Washington metropolitan area -an area of about 7,000 square miles, roughly 70 miles wide and 100 miles long in a northeast-southwest direction-had to be modeled.

In setting up the model of each aquifer, the transmissivity distribution shown in figures 2 4 and a uniform storage coefficient ${ }^{2}$ of 0.0002 were used. Outcrop areas along the inland edge of the Coastal Plain were treated as recharge boundaries along which water levels remain constant and are not affected by the development of the aquifers. The other boundaries of the model area were treated as being impermeable (no flow across the boundary in either direction). The model area and the approximate

\footnotetext{
2 The storage coefficient is the volume of water an aquifer releases from or takes into storage per unit surface area of the aquifer per unit change in the water level of the aquifer.
} 
location of the boundaries are shown in figure 5. In the absence of reliable data on the hydraulic properties of extensive saturated silt and clay layers that overlie and are interbedded within the aquifers, it was assumed that no water leaked through or from these layers and that the outcrop areas were the only source of recharge to the aquifers. In all probability some water does leak from associated fine-grained materials, and therefore the computations of water availability and water-level effects are conservative; that is, the computed water yields are probably lower than actual yields, and the computed water-level declines are probably greater than actual declines.
WATER-SUPPLY POTENTIAL

For the purpose of this analysis, the watersupply potential of an artesian aquifer in an area of interest was defined as the maximum quantity of water that can be withdrawn continuously from the aquifer, within the area of interest, without dewatering the aquifer; that is, without lowering water levels below the top of the aquifer. In estimating the watersupply potential, as defined above, of the Coastal Plain aquifers in the Washington metropoli$\tan$ area, the area of interest was assumed to lie within a 30-mile radius of Washington, D.C. Each of the three aquifers was modeled separately by imposing a gradient equal to the
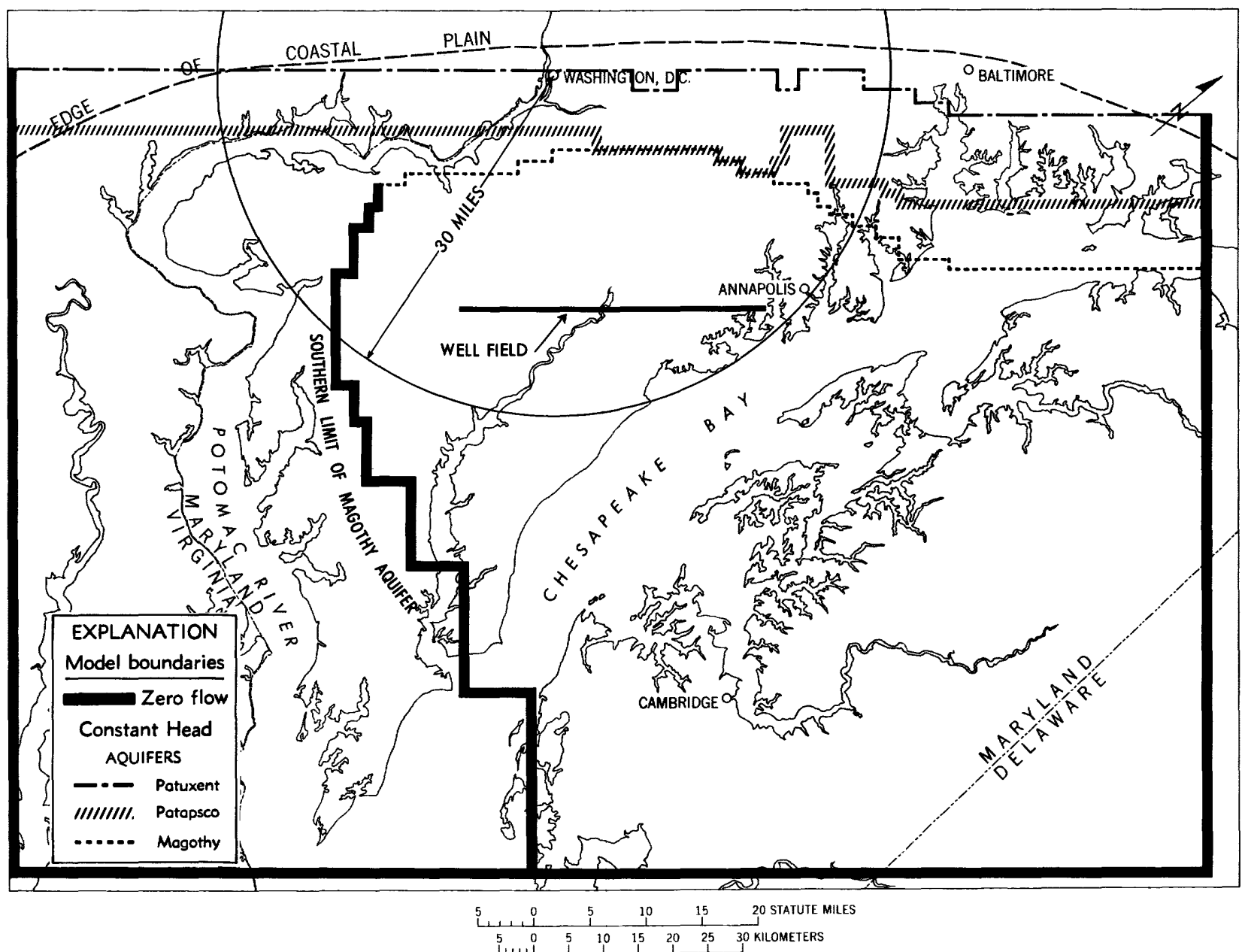

FIGURE 5.-Model area and locations of boundaries and of hypothetical well field. 
dip of the aquifer between the recharge boundary along its outcrop area and a semicircle at the assumed 30-mile radius from Washington. (See fig. 5.) That is, the water levels along the semicircle were assumed to be lowered to the top of each aquifer while water levels were assumed to be unaffected along its recharge boundary. The steady flow computed for these conditions was taken as the potential of the aquifer. Thus, the water-supply potential of the Coastal Plain aquifers was computed to be about $\mathbf{4 0} \mathrm{mgd}$ from the Magothy, $50 \mathrm{mgd}$ from the Patapsco, and $80 \mathrm{mgd}$ from the Patuxenta total of $170 \mathrm{mgd}$ from all three aquifers. Considering the estimated present pumpage of 60 $\mathrm{mgd}$, the additional quantity of water that could be developed from these aquifers, on a continuous basis, is $110 \mathrm{mgd}$.

\section{EMERGENCY WATER SUPPLY}

The assumed $100 \mathrm{mgd}$ for an emergency water supply is slightly less than the additional $110 \mathrm{mgd}$ of water that could be developed from the Coastal Plain aquifers. Furthermore, pumpage for an emergency supply would not be continuous. Therefore, in terms of water availability, it is possible to develop the assumed emergency supply. The analysis in this case was made to determine the effects of such a development on the regional water levels.

The first step in the analysis was to choose an example of an area, within the assumed 30 mile radius of Washington, where the emergency supply could be developed with a relatively high yield well field. Several computer solutions of the model were made, each with a different assumed location for a well field. On the basis of these solutions, an area that lies on a northeast-southwest line east of Washington, as shown in figure 5, was selected for the hypothetical location of such a well field. The combined transmissivity of the aquifers at this location is relatively high, and their depth allows for large drawdowns and, consequently, high well yields. There are probably other areas having a similar potential, and additional data and analysis could indicate that locations other than the one here selected are preferable.

The second step of the analysis was to assume a pumping schedule according to which the assumed 100-mgd emergency supply would be developed from the hypothetical well field. It was assumed that pumpage during 100 consecutive days, recurring in each of 3 consecutive years of drought, might be necessary. Such assumed conditions represent an extreme drought. Thus, the computation sequence comprised a 100-day pumping cycle followed by a 265-day recovery, a second pumping cycle of 100 days followed by a 265-day recovery, and a third 100-day pumping cycle, after which the sequence terminated.

Initial computer solutions of the model indicated that the Magothy aquifer contributed 46 percent of the well-field yield, the Patapsco 41 percent, and the Patuxent 13 percent. The low contribution of the Patuxent aquifer to the yield of the well field and its depth and thickness at the location of the hypothetical well field-about 1,400 feet below land surface and about 400 feet thick-led to the assumption that it would be preferable to develop the emergency supply from the upper two aquifers, the Magothy and the Patapsco. Thus, well depths are considerably reduced in exchange for a relatively small increase in the drawdown of the water levels.

On the basis of all these assumptions, the model was operated using the combined transmissivity of the Magothy and the Patapsco, a storage coefficient of 0.0002 , and a pumpage of $100 \mathrm{mgd}$ from the well field according to the pumping schedule given above, and the effects of the pumpage on the regional water levels were computed. The areal extent and magnitude of the drawdown around the hypothetical well field, at the end of the third 100-day pumping cycle, is shown in figure 6 .

\section{SUMMARY AND CONCLUSIONS}

The results of the preliminary simulation study suggest that developing a large water supply from the Coastal Plain aquifers in the Washington metropolitan area is physically possible. In the study, no consideration was given to legal, political, and economic constraints or to other nonhydrologic factors.

According to the model, the water-supply potential of these aquifers-the quantity of 


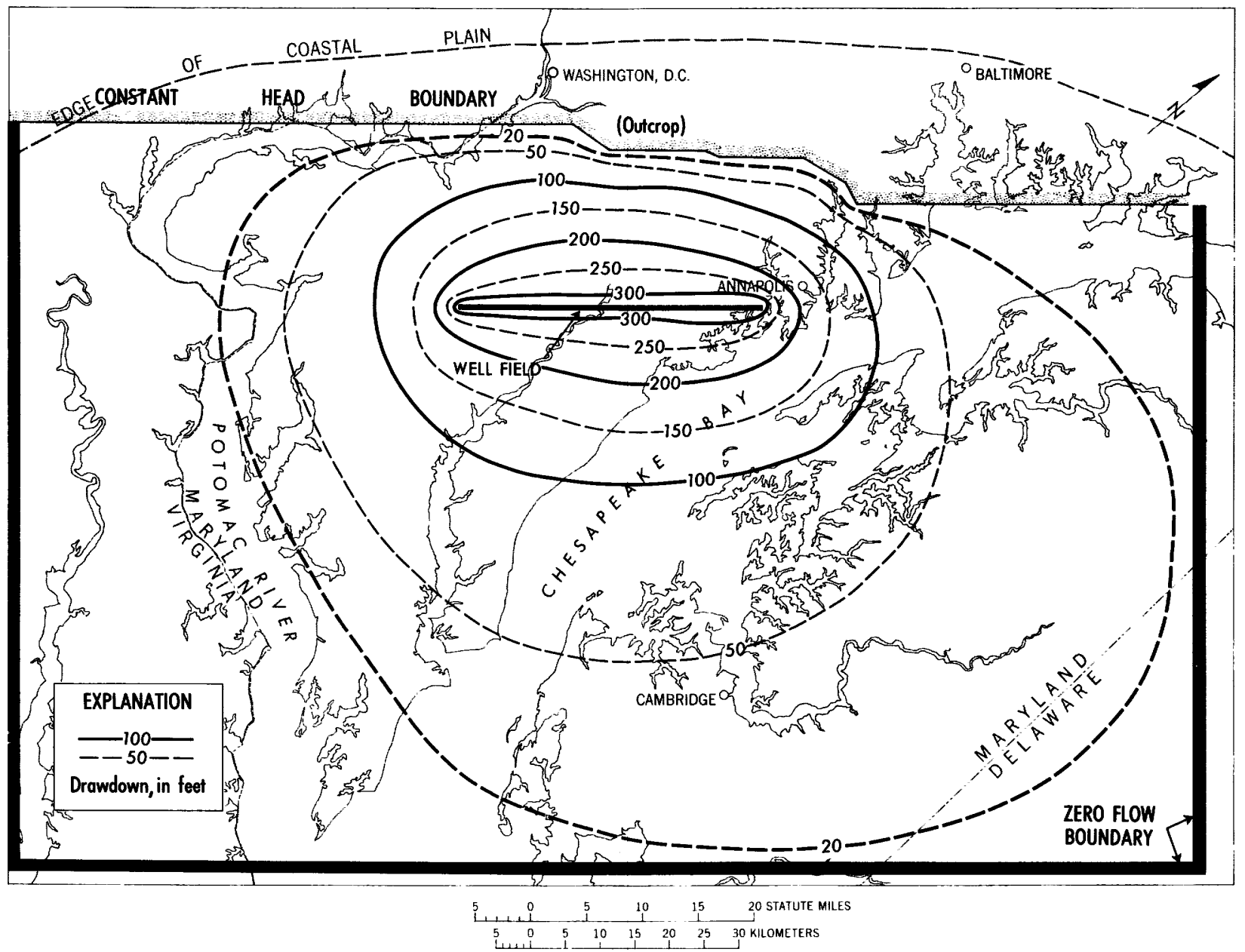

FiguRe 6.-Drawdown at the end of the third 100-day pumping cycle.

water that can be continuously withdrawn from these aquifers within an assumed 30-mile radius of Washington-is about $170 \mathrm{mgd}$. Present pumpage in the area is estimated to be 60 $\mathrm{mgd}$; therefore an additional $110 \mathrm{mgd}$ could be developed from these aquifers. No allowance was made in the model for recharge by leakage from or through confining beds. The data available do not permit a reliable estimate of the leakage that can be induced by pumping; however, the water-supply potential of the aquifers might be much larger if recharge from leakage occurs. Additional studies would be necessary to determine the impact of such large-scale continuous withdrawals from the aquifers on water levels and streamflow. Studies would also be necessary to evaluate potential hazards of land subsidence and salt-water encroachment.

Under an assumption of intermittent pumping for an emergency supply of $100 \mathrm{mgd}$, the model indicates that the supply can be developed through a properly designed and positioned well field. For such short-term pumpage (100 days, as assumed), most of the pumped water will be derived from storage within the Magothy and Patapsco aquifers. The forecasted drawdown distribution around the hypothetical well field, shown in figure 6 , indicates that development of the assumed emergency supply would lower the regional potentiometric surface of the aquifers for a considerable dis- 
tance from the well field. As a consequence of pumping, water levels would be lowered in many wells; thus pumping costs would be increased or yields would be decreased for many other users of ground water in the area. The effects of development would gradually diminish, as water levels recovered, and would disappear if the time between droughts is sufficient to allow full recovery of water levels.

The provisional estimates gained from this preliminary study indicate that the Coastal Plain aquifers, extending eastward from Washington, D.C., represent a large water-resource potential that may bear importantly on the future growth of the metropolitan area. However, if large-scale development of the water resources is ever contemplated, the nature, degree, and extent of all consequent effects of obtaining water from the Coastal Plain aquifers should be accurately evaluated.

Further field investigations for obtaining additional data for more reliable estimates of the potential of the Coastal Plain aquifers and of the effects of large-scale development of these aquifers would improve the reliability of the results. A testing program to obtain additional data on the properties of the aquifers and on the properties of the finer grained confining beds could consist of a set of drilling and testing procedures implemented at several sites where data are needed. An outline for procedures that could be followed at each typical test site is presented below:

1. Drill a probe hole through the Coastal Plain sediments to bedrock, obtain formation samples, and run geophysical logs.

2. On the basis of the above, identify the principal water-bearing zones.

3. Drill a test well, the well to be constructed so that each principal water-bearing zone can be pumped individually or in combination with one or more adjacent zones.

4. Convert the probe hole to an observation well in the deepest zone and drill additional observation wells. Two observation wells, ideally, would be completed in each principal zone at distances of approximately 200 feet and 2,000 feet from the test well, respectively.

5. Make aquifer tests. Each principal zone could be tested individually by isolating it in the test well. A final test could be made with the test well open to all zones. The tests, ideally, would have a minimum duration of (1) 7 days pumping and 7 days recovery for the uppermost zone and the final test and (2) 3 days pumping and 3 days recovery for all other zones.

An idealized well configuration for a test site is shown in figure 7. Although the number and depth of productive zones may differ from site to site, it was assumed that four productive zones at depths of 500, 800, 1,000 and 1,500 feet below land surface would typify the principal test sites. At some sites the data obtained from the probe hole may possibly indicate that further testing is not warranted.

A testing program similar to the one outlined above would provide data for a more reliable model to estimate ground-water availability and to select optimum well-field locations for emergency water supplies. It would also provide data necessary for proper well and wellfield design and information on the quality of ground water in different areas and formations. However, the data currently available plus new data obtained by the drilling and testing program would still answer only some of the questions related to the water-supply source and would not provide all the answers to all the cause-effect questions that may be raised.

A unique advantage of a ground-water source is that it may be developed incrementally as need and economics dictate. Although the drilling and testing program would add significantly to the data base, the experience to be gained from observing the response of the regional hydrologic system to a subsequent incremental development as a source of supply will provide the most reliable basis for evaluating the long-term impact of large-scale continuous use. 


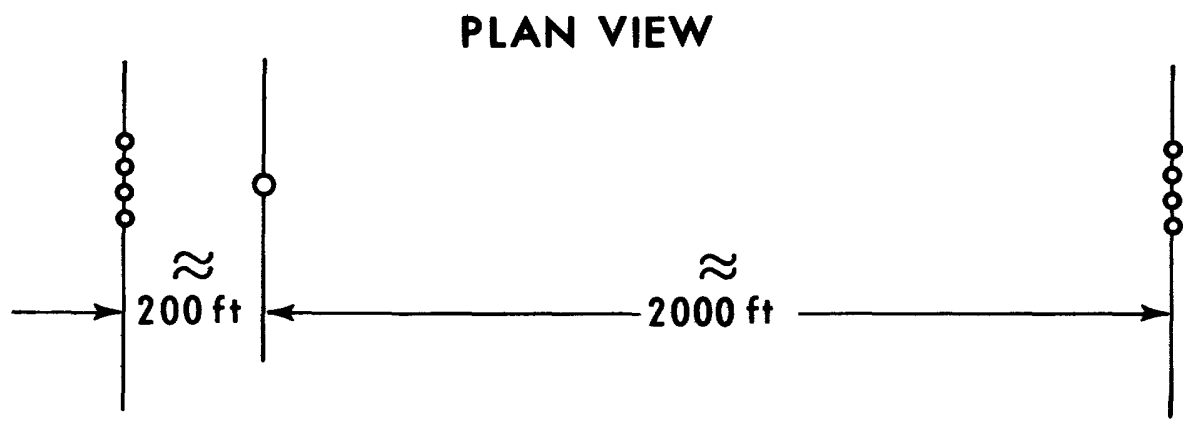

SECTION VIEW

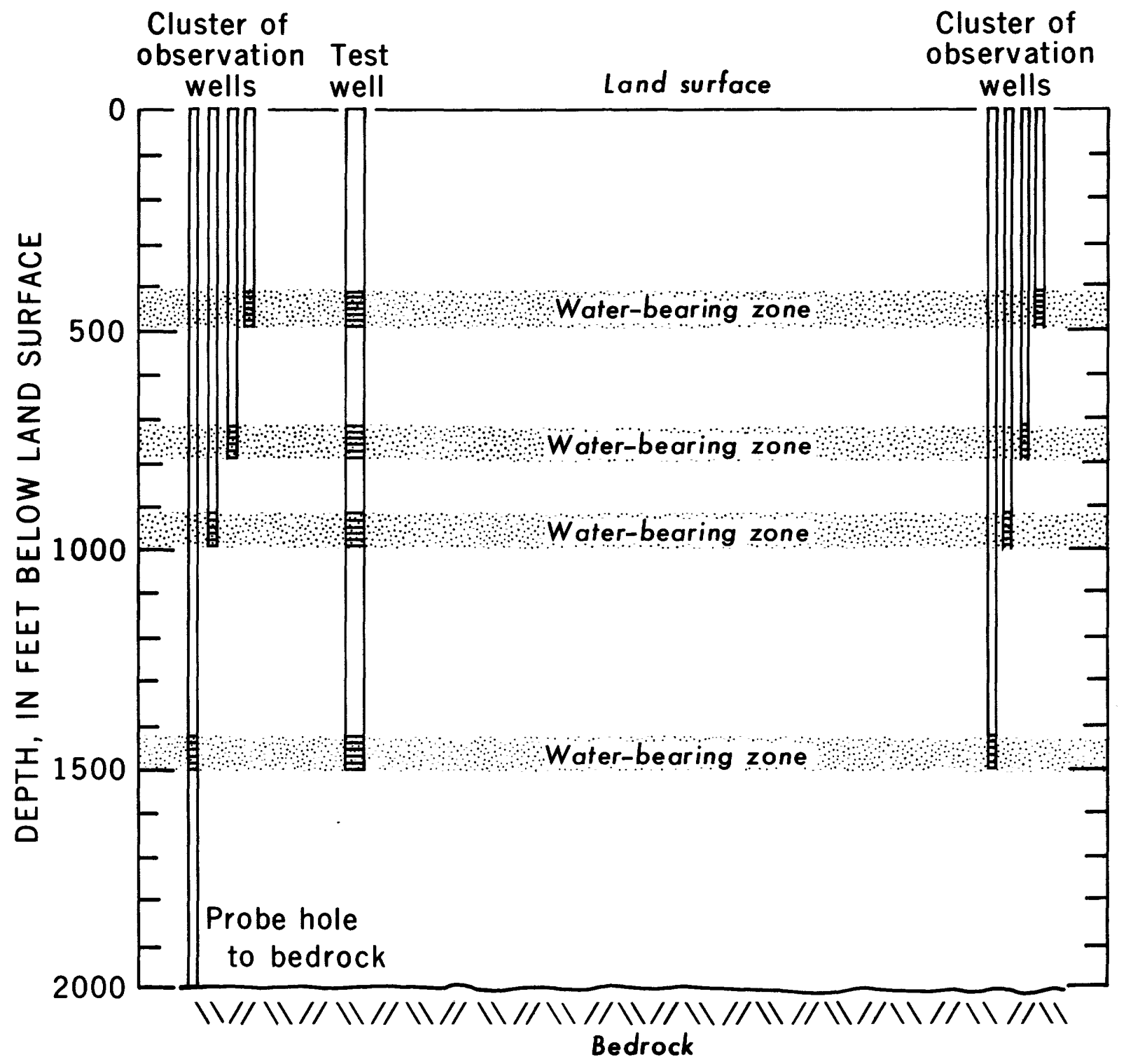

FIGURE 7.-Plan and section of idealized well configuration at a test site. 


\section{REFERENCES}

Back, William, 1966, Hydrochemical facies and groundwater flow patterns in northern part of Atlantic Coastal Plain: U.S. Geol. Survey Prof. Paper 498A, 41 p.

Bennett, R. R., and Meyer, R. R., 1952, Geology and ground-water resources of the Baltimore area: Maryland Dept. Geology, Mines and Water Resources Bull. 4, 573 p.

Brookhart, J. W., and Bennion, V. R., 1949, The water resources of Anne Arundel County: Maryland Dept. Geology, Mines and Water Resources Bull. $5,149 \mathrm{p}$.

Brown, P. M., Miller, J. A., and Swain, F. M., 1972, Structural and stratigraphic framework, and spatial distribution of permeability of the Atlantic Coastal Plain, North Carolina to New York: U.S. Geol. Survey Prof. Paper 796, 79 p.

Cederstrom, D. J., Baker, J. A., and Tarver, G. R., 1971, North Atlantic Regional Water Resources Study, Appendix D-Geology and Groundwater: U.S. Geol. Survey open-file report, 240 p.

Crooks, J. W., O'Bryan, Deric, and others, 1967, Water Resources of the Patuxent River basin, Maryland: U.S. Geol. Survey Hydrol. Inv. Atlas HA-244.

Cushing, E. M., Kantrowitz, I. H., and Taylor, K. R., 1973, Water resources of the Delmarva Peninsula: U.S. Geol. Survey Prof. Paper 822, 58 p.

Hansen, H. J., III, 1972, A user's guide for the artesian aquifers of the Maryland Coastal Plain, Parts 1 and 2: Maryland Geological Survey.

Johnston, P.M., 1964, Geology and ground-water resources of Washington, D.C., and vicinity: U.S. Geol. Survey Water-Supply Paper 1776, 97 p.

Johnston, P. M., Pollock, S. J., and Weist, W. G., Jr., 1962, Ground-water resources of the Potomac
River Basin, Appendix G.: Potomac River basin report, U.S. Army Corps of Engineers Dist., Baltimore, Md.

Mack, F. K., 1962, Ground-water supplies for industrial and urban development in Anne Arundel County: Maryland Dept. Geology, Mines and Water Resources Bull. 26, $90 \mathrm{p}$.

1966, Ground water in Prince Georges County: Maryland Geol. Survey Bull. 29, 101 p.

- 1974, An evaluation of the Magothy aquifer in the Annapolis area, Maryland: Maryland Geol. Survey Rept. of Inv. (In press.)

Meyer, Gerald, 1952, Ground-water resources, in Geology and ground-water resources of Prince Georges County: Maryland Dept. Geol., Mines and Water Resources Bull. 10, p. 82-254.

Otton, E. G., 1955, Ground-water resources of the Southern Maryland coastal plain: Maryland Dept. Geology, Mines and Water Resources Bull. 15, 347 p.

Otton, E. G., Martin, R. O. R., and Durum, W. H., 1964, Water resources of the Baltimore area, Maryland, U.S. Geol. Survey Water-Supply Paper 1499-F, $105 \mathrm{p}$.

Pinder, G. F., 1970, An iterative digital model for aquifer evaluation: U.S. Geol. Survey open-file Rept., 44 p.

Slaughter, T. H., and Otton, E. G., 1968, Availability of ground water in Charles County: Maryland Geol. Survey Bull. 30, 100 p.

Trescott, P. C., 1973, Iterative digital model for aquifer evaluations: U.S. Geol. Survey open-file Rept., 63 p.

Weigle, J. M., Webb, W. E., and Gardner, R. A., 1970, Water resources of southern Maryland: U.S. Geol. Survey Hydrol. Inv. Atlas HA-365.

*U.S. GOVERNMENT PRINTING OFFICE: $1974-543-583 / 110$ 
